\title{
Effects of Industrial Park Induced Displacement on Natural, Economic and Social Assets of Small-Scale Farm Holders in Peri-Urban Area of Kombolcha, Ethiopia
}

\author{
Habiba Yesuf \\ Department of Public Administration and Development Management, Mekelle University, Ethiopia
}

\begin{abstract}
To carry out various infrastructural and developmental projects displacement of local peoples from their original land becomes increases. This imposes cost for the poor and marginalized peoples due to the failure to restore their livelihood. Industrial parks are one of the state vital infrastructures to promote industrialization and economy reformation in Ethiopia. At this time government is highly committed in attracting investors to increase FDI (Foreign Direct Investment) of the country. FDI driven by investor's interest in new industrial park development. The availability of large plot of land including low cost of production, and the increasing demand of FDI triggered IPD (Industrial Park Development) in the study area.The only option for government might be expropriating agricultural land and make available for investment activities. However, the establishment of IP (Industrial parks) fails to exemplify the community context.As a result, this study aimed at explaining effects of Industrial Park Induced Displacement (IPID) on natural, economic and social asset of small scale farm holders in peri urban area of kombolcha city, Amhara, Ethiopia. Furthermore, the study explained about the property rights held by small scale farm holders whose land were expropriated, and how were the small scale farm holders affected by expropriation compensated, the changes in livelihood (natural, economic and social asset) of the displaced farm holders, what areadaptation strategies adapted by households to deal with the new changing conditions. In order to carry out this study, primary and secondary data collection sources such as semi structured interview, observation, desk review, and content analysis of relevant secondary sources have been used. Accordingly, qualitative analysis employed for analyzing the findings of the study.Expropriation of land for IPD implemented with no consultative, consent, and honest involvement of the displaced farm holders. This showed that IPD deprived property rights of displaced farm holders by changing land use from agricultural land towards non farming activity. Furthermore, delay in compensation provision, corruption, and improper calculation generated insignificant amount of compensation. The result of this study indicated that IPD affected displaced farm holders' access to farm land, grazing land and natural resources, this generated landlessness, joblessness and triggered economic marginalization.of the displaced. Additionally, their relationship with neighbours, their engagenement in labor association and their mutual supporting mechanisms also affected. Moreover, the study depicted out that displaced farm holder's livelihood adaptation strategies rely on off-farm employment (as permanent and temporary worker), and most of the displaced are fails to adapt.
\end{abstract}

Keywords:IPID, Expropriation, Property rights, Compensation, Natural asset, Economic asset, Social asset, Livelihood adaptation strategies, Small-scale farm holders

DOI: $10.7176 /$ RHSS/11-15-02

Publication date:October $31^{\text {st }} 2021$

\section{INTRODUCTION}

Dominant idea of development informs the overall benefit that it can bring to the society. Countries in both developed and developing nations they put in place policies and practices to achieve development goals such as eliminating and reducing poverty and creating employment opportunity etc. Furthermore, projects related with the construction of dams to generate electric power, conservation project, mining, industrial plants, military installation, airports, weapon testing grounds, infrastructural development and other activities (Robinson, 2003, Stanley, 2009, Vanclay, 2017). Even though, such developmental projects provide enormous advantages for the society however, it is also imposing cost for the poor and marginalized peoples without their readiness to migrate from their living place.

Industrial parks (IPs) are one of the state's vital infrastructures to promote industrialization and economic restructuring. Presently, development of IPs has become a world wide trend. More importantly, for developing countries, they are justified by their role in maximizing resource integration within a certain area, domestic and foreign investment in attracting labour and capital intensive and increasing job opportunities and wages for local worker (Mendes, Bertella, et.al., 2014). They are also justified by the fact they can link the local economy to the global economy by making use of comparative advantages. To this end, governments need to provide public goods such as land, space, water, security, electricity and others. The effects of industrial parks are presented as mixed. They provide a new business environment, transfer techniques and technologies, and improve the industry landscape of countries in terms of number and purpose (Noufal and Ramachandran, 2016, Navarra, Niehof, et al., 
2012). Despite their varying purpose, IPs requires land that can lead to displacement of local peoples and disruption of livelihood. Further, ill informed, non negotiated and badly implemented displacemnt projects complicate the economic, social and livelihood aspect of local people ( Terminski, 2013, Stanley, 2009, Vanclay, 2017).

In Ethiopia, IPs is one of the fast growing and expanding development infrastructure sectors. This is dueto government's firm position in creating economic growth, export oriented economy and providing job opportunity to its growing population. As stated in country's Industrial Parks proclamation (proclamation 886/2015) they are mainly established for: “"

1) Contributing towards the development of the country's technological and industrial infrastructure;

2) Encouraging private sector participation in manufacturing industries and related investments;

3) Enhancing the competitiveness of the country's economic development; and creating ample job opportunities and achieving sustainable economic development" (Azmach, 2019, p.25).

In 2017, Ethiopia government received a positive response from China and the United Nations Industrial Development Organization (UNIDO) to work collaboratively to strengthen collaboration on IPs development to will to the countries to join the group of middle-income countries by 2025 .

Furthermore, development in outskirt area mostly related to spatial pattern of land use change of peri-urban agricultural land that eventually forces people to displace from their original land who lack property right and lack of tenure security (Alemu, 2015).

Therefore, an in depth analysis of IPs in each context is vital to inform polices and practises to bring an inclusive economic growth. Explaining the effect of industrial park induced displacement (IPID) on the natural, economic and social asset of small scale farm holders in the study area was the main aim of this study.

\section{LITERATURE REVIEW}

\subsection{Development}

"Development is the overall welfare increment of the society in every aspect whether economic, political and social. Development refers to the situation where both material and quality living standard of masses will increase" Lone (2014, p.271). Many developmental projects had been constructed such as dams, industrial plants, railway lines, roads, urban renewal, economic processing zones and many other infrastructural activities (Lone, 2014, Cernea, 2000). However, in the name of development several peoples were displaced with insufficient payment for their loss (Lone, 2014).Thereafter, the life of the displaced peopleis in danger to alleviate their economic problem, miserable living condition and vulnerability in the future (Lone, 2014, Wilmsen, Webber, et al., 2011). Accordingly, this is a contradictory circumstance, theoretically development give emphasis to overall welfare, empowerment and wellbeing of human kind whereas practically development fails to attain the stated goals due to the mismatch among the vision of development and the actual result. Moreover, the promises of development are often much bigger than what is achieved in reality. Development induced displacement (DID) challenges the sustainability of developmental policies and practices that arouse resistance, campaign and questioning of policy formulators, planners and different governmental authorities (Lone, 2014).

\subsection{Peri-Urban Development}

Regional economic growth and industrialization trigger the demand of land to embark developmental activities in peri-urban areas of both developing and developed countries because it is the place in which multitude of land use claims are carried out and the area in which the rural and urban life meet up (Woltjer, 2014). He also explains that Peri-urban development is driven by "foreign direct investment" (FDI) it called global capital decision. This provides an opportunity to locate manufacturing plants in the area, due to various potentials related to the cheapest cost of production, the availability of large plot of land, and possibility in which to cluster manufacturing firms in nearby industrial estates (Woltjer, 2014).

Moreover, it is very complex to identify the dynamic change of development and its characteristics in peri-urban area. Because, a rapid transformation of land use from agricultural to non-agricultural practice creates significant effect on socio-economic condition of rural society (Woltjer, 2014). Accordingly, this rapidland conversion in peri-urban areas tends to create substantial effects concerning agricultural employment, reduction of major agricultural plot, and food insecurity of the small-scale farmers (Woltjer, 2014). In developing country land is the most important social, economic, political, cultural asset and peri-urban agricultural land have still significant role for the livelihood of local peoples (Alemu, 2015).

\subsection{Concepts of Displacement}

Displacement is one of significant element to carry out various developmental projects such as construction of dams, highways, railways, conservation project, industrial plants and other infrastructural projects (McDonald Wilmsen and Webber, 2010, Randell, 2016, Robinson, 2003, Stanley, 2009, Vanclay,2017). However, roughly more than 10,000,000 people every year are forced to move out from their home land /livelihood and in the last 
period of $20^{\text {th }}$ century between $90-100$ million peoples displaced to make a way for infrastructure construction (Randell, 2016, Cernea, 2000, Azuela and Herrera Martin, 2009, Downing, 2002).

In addition to the above, when there are public or private projects that need to be carried out government uses power of eminent domain instead of building support through negotiation and consultation with the local peoples (Vanclay, 2017, Azuela and Herrera Martin, 2009). Power of eminent domain described as government use of legal rights to compulsorily obtain property of individuals for public use against their consent (Jamart, 2010). Moreover, it implies the way of expropriating property that privately owned for the interest of the public either by local, federal and state government (Merriam, 2007).

Regardless of the aim of the project either instigates by government or private investors large scale infrastructural projects demand large tract of land this result displacement of local peoples (Vanclay, 2017, IFC, 2012). Displacement is not about eviction from dwellings and it also about expropriating agricultural landand other assets (capitals) of the displaced peoples (Cernea, 2000, Downing, 2002). In some situations, the affected peoples might not be needed to move physically from the area, however the project or development that carried out in the area may still have effect on their livelihood (Vanclay, 2017).

Ambaye (2009, p.4) cited "expropriation is the right of the nation or state, or of those to whom the power has been lawfully delegated, to condemn private property for public use, and to appropriate the ownership and possession of such property without the owner's consent on paying the owner a due compensation to be ascertained according to law" (Francis, Amendola, William, John, and Kennel). This expropriation of land from the owners for urban development or infrastructural projects takes place by putting the reason that achieving public interest is significant when the public need is much more substantial than the individual owner.

Accordingly, compulsory land acquisition through expropriation and sometimes forceful eviction affect social as well as their economy of individual property owner and the peasant whose livelihood depends onthe land (Vanclay, 2017, Azuela and Herrera Martin, 2009, Eerd and Banerjee, 2013). Further, most frequently thepractice of eviction, expropriation and compulsory acquisition of land occurs with little or no informed consent as well as with little or no payment of compensation for the affected peoples (Eerd and Banerjee, 2013).

Payne (2001,p.416) defined "Property right as a recognized interest in land or property vested in an individual or group and can apply separately to land or development on it". Jacobs (2013) stated property rights are a means of survival and it is closely related to fulfilment of the right to life including other human rights of individuals that enjoyed from the bundle of sticks or combination of those sticks.

Practically, various rights can be activated in similar plot like the right to use the land or use right involves using the land for raising several crops and for the purpose of grazing and to collect forestry products (Feder and Feeny, 1991). In addition, the rights to control include the right to decide how the land should be used, including to make decisions about the kind of crops to be planted in order to get financial benefit by selling various crops. Furthermore, the right to transfer includes transfer property to inheritors through means of inheritance as well as reallocating control and use rights.

Expropriation must not be implemented without the consent of indigenous peoples (IFC, 2012), however development in developing world has been compulsory to confront an extensive asset loss (Naika, 2016). A very useful for this well-defined idea is (FPIC) Free, prior, informed, consent (Adeola, 2017). According to Adeola (2017) for development actors starting from free, prior, informed consent (FPIC) is significant to ensure that displaced peoples have feeling of belongingness for the procedure of consultation and to promote sustainability of development. For instance, construction of dams and industrial corridors convert the land to the construction of those projects causes' local communities to miserably displace from their livelihood and to lose their property rights (Naika, 2016).

\subsection{Compensation}

As cited in Ambaye (2009, p.8) "compensation is described as a full indemnity or remuneration for the loss or damage sustained by the owner of the property taken or injured for the public use" (Francis, Amendola, William, John, and Kennel). A payment in cash/ in kind to which the displaced peoples are entitled to substitute loss of assets, resources as well as their income called compensation (Dowmimg, 2002, Randell, 2016). In order to handle expropriation, forceful displacement as well as resettlement the governments in most countries uses compensation as a sole financial instrument (Cernea, 2008). Furthermore, it can be paid at market price or replacement, future price as well as current price. However, in some cases some resource loss was not included in compensation package as such shifting cultivation and community grazing land (Sayatham and Suhardiman, 2015). In most developing countries, compensation for the loss of asset and land is legally compulsory, economically reasonable and very crucial; however, it is incapable to achieve the restoration as well as recovery of livelihood (Cernea, 2008). He also explained that due to lack of finance, corruption and other structural reasons compensation is not enough to achieve full restoration and incapable to improve livelihood of the affected people.

Consequently, just and fair compensation is critically essential to make the financial situation and the living condition of land owners to remain the same or better despite the expropriation (Viitanen, 2002). Additionally, 
before expropriation completed full compensation should be paid for the displaced (Viitanen, 2002). According to Reddy, Smyth, et al. (2017) the best and appropriate way of compensation strategy for rural communities is replacement of land, when the displaced peoples compensated in cash or replacement land in order to avoid the complication associated with price inflation and speculation.

Compensation should be enough to enable the displaced peoples to obtain the lost property that even equivalent or even exceed to the pre-displacement condition (Vanclay, 2017).

Certainly, financing be able to supplement a portion of benefits that generates by the project to complement the compensation payment. For instance, Brazil and Colombia adopted benefit sharing through royalties' distribution and transfer, and China, Canada and Norway also applied the supplement of compensation through sharing of the project benefit for the displaced peoples (Cernea, 2008). Furthermore, benefit sharing is very indispensable when forced displacement becomes inevitable to restore lost asset of displaces in sense of development.

\subsection{Livelihood}

Chambers Conway's (1992) definition about livelihood incorporated by Department for International Development (DFID):

"A livelihood comprises the capabilities, assets and activities required for a means of living. A livelihood is sustainable when it can cope with and recover from stresses and shocks and maintain or enhance its capabilities and assets both now and in the future, while not undermining the natural resource base" (DFID,2000,p.1). On the basis of this definition, livelihood implies the comprehensive aspect that encompasses the financial, economic, human, cultural and social resources that necessary for means of survival.

Scoones (1998) specifies that sustainable rural livelihood can be attained by combining social, human, financial and natural capitals through control over and access to those resources. Accordingly, households are more vulnerable when displacement from the original place creates stress, shock and asset loss or their means of survival (livelihood). For this study I only describe natural, financial (economic), and social asset.

Loss of Natural asset: it involves all-natural resources (land, water, soil, air etc) and the resource flows from environmental services essential for the individuals who need to obtain their livelihood from the resources-based activities like farming, fishing, and gathering wood in forests. There is close relation among the natural asset and the context of vulnerability because many shocks destroy the livelihood of the poor (DFID, 1999). Landlessness implies partly or total loss of their farmland or non-farm land (Cernea, 2000). He specified that, if this land is not replaced by other land the household's and orther displaced families have become impoverished this landlessness also involves community grazing land and other common resources.

Economic Assets: it concerns about loss of economic resource for the restoration of livelihood such as land and agricultural farming activity (job) is major impact on the economy of the affected peoples. Land is essential asset for the peoples whose means of living depends on the land, though landlessness generates high impoverishment and risk (Cernea, 2000). Moreover, the peoples spent their whole life in farming practice and doing various agricultural activities. Therefore, losing their land results joblessness. This creates a lot of difficulties among displaced people to perform any other job (Cernea, 2000). He also explains that, after long period of displacement, unemployment and under employment being continued. Furthermore, the dispcaed peoples access to common property becomes restricted this affects their way of income generation as well as their productivity.

Social disruption: Development induced displacement disrupts the social network, kinship, threaten place attachment or sense of identity, separate collaborative production system and enlarge health risk of displaced peoples (Robinson, 2013). Mostly, planners failed to take in to consideration about local context related to social connection of societies as well as people's way of living. Due to that the affected people's loss cultural resources, economic resources, it creates social trauma, economic distress results risk of impoverishment. Cernea (2000) specifies social disarticulation due to forceful displacement hampers social capital of the displaced persons and it separates their relationship, inter-personal bond, social institutions and social network. It is genuine loss that has long term consequences to rebuild or re-establish the community. Lack of free, prior, non-consultative, poor planned and implemented project results impoverishment and social disruption (De Wet, 2009, Hanna and Vanclay, 2013). Downing (2002) explains that due to failure to avoid or alleviate those risks (landlessness, joblessness, marginalization, food insecurity, social disarticulation, common property and service loss) a lot of displaced peoples already suffer, because it generates new poverty and they become even poorer. Loss of resources even small amount it hampers human dignity and daily survivability of the poor.

\subsection{Livelihood adaptation strategies}

The capability of displaced farm holders to restore their livelihood after displacement based on obtaining job in non-agricultural sectors (Wilmsen, Webber, et al., 2011). Accordingly, employment opportunity plays a crucial role for displaced peoples in order to supplement their income. Due to that displaced peoples usually change their 
job in response to losing or decreasing of natural asset that once supported their employment (Wilmsen, Webber, et al., 2011).

In order to deploy rural households' adaptation strategies, it can depend on other types of assets, the substitution of the existing livelihood assets with other types of assets is quite essential (Ellis, 2000, Krantz, 2001, Hussein, 2002, DFID, 1999). However, replacement of livelihood asset is achieved when there are various livelihood substitutes in the rural households, because outside their farming activity they have lack of technical skills and expertise with regard to adopting various alternative occupations (Sayatham and Suhardiman, 2015).

The economic and social well-being of the displaced peoples might dominantly influenced by stress or shock in time displacement due to that some peoples become less likely to deal with or adapt to the changing conditions (Wilmsen, Webber, et al., 2011). They also mentioned that due to lack of getting an alternative employment opportunity some peoples face substantial challenges in restoring loss of assets as well as getting adequate income.

\section{MATERIAL AND METHODS}

\subsection{Description of the Study Area}

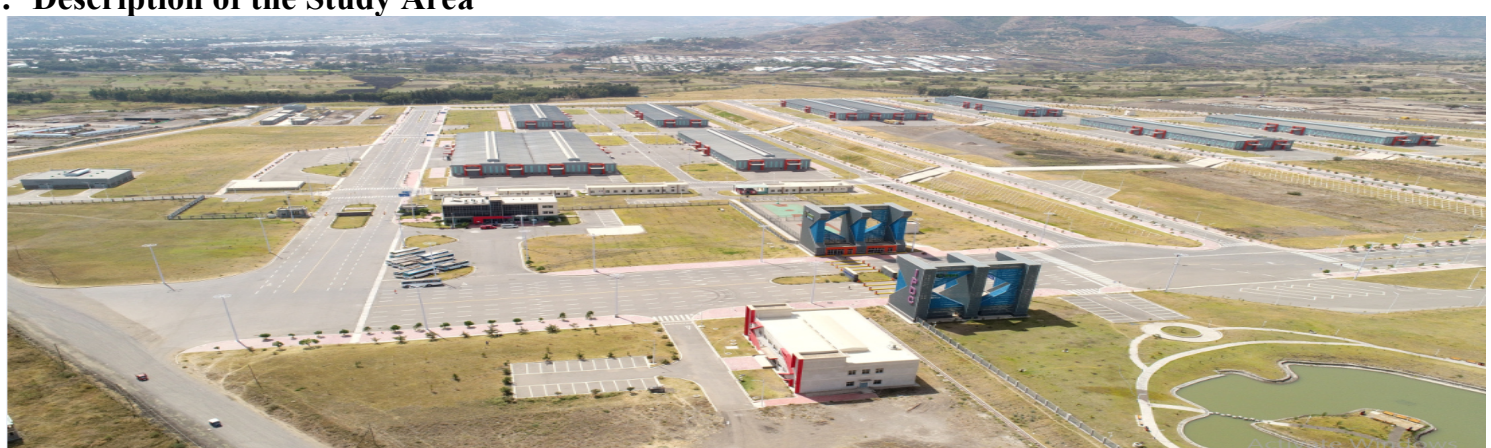

Photograph 1: Study area

Kombolcha city found in Region of Amhara, Ethiopia. The number of populations in Kombolcha has 93,605, it makes the city $4^{\text {th }}$ largest city in the Region next to Bahirdar, Gonder and Dessie. Kombolcha is one of growing cities in Ethiopia that rezoned to be industrial area for the region as well as for the country. The location of the city situated 31.74 longitudes, 11.08 latitude; and it is located at elevation of 1883 meters above sea level. Strategic location of Kombolcha city is around $376 \mathrm{Km}$ far from Addis Ababa (capital city), 505Km far from the regional capital (Bahirdar), 480Km away from port Djibouti and 390Km far from Assab port (Eritrea).

This makes the city more attractive for various investment activities. These IPD declared in 2014 by federal government and lower government officials expropriated the farm land in 2015 from the farm holders in peri-urban area of kombolcha called kurangoye community. IP built on 75 hectares of land equals to $750 \mathrm{Km}^{2}$. A total of 9 factory sheds, 2 sheds with $11,000 \mathrm{~m}^{2}$ and 7 sheds with $5,500 \mathrm{~m}^{2}$. All sheds reserved with the companies from Italy, USA, South Korea and China. Moreover, on the other 10 hectares of land the offices and residential house for the investors of IP were built. Thereafter, the IP inaugurated in 2017.

The small-scale farm holders are farmers and agrarian society in kurangoye. They are the indigenous communities culturally, socially, economically attached with the area since they were born. The family size ranges from 3-9 members in households. Their age ranges from 43-76 years. They got their farm land, grazing and trees through inhiretance from their ancestors it has passed from generation to generation. Almost all of the small-scale farm holders are uneducated (they can't read and write) except some of their children are educated. They spent their whole life by doing agricultural activities and partially, cattle breeding and forestry. Accordingly, their main means of living depends on the land.

\subsection{Research Design \& Data Sources}

This study used explanatory research approach it aims to explain the effects of industrial park induced displacement (IPID) on natural, economic and social asset of small-scale farm holders in peri-urban area of Kombolcha. Furthermore, the researcher employed a case study research strategy this helps to explain the problem to be studied. Qualitative method of data collection was employed through collecting information from primary and secondary sources. Moreover, primary source of information gathered through interview, and observation in the field.

In this study the researcher used semi-structured interview by employing open and close ended questions for displaced small-scale farm holders to get detail information and also for government officials who have connection with the subject under study. Additionally, observing the respondents feeling was important so as to get some hidden information that the respondents may not disclose it using interview methods. Besides that, observing land use change of the study area was also included. While secondary source of data gathered through analyzing several 
documents and other existing sources such as constitutions, legislations, and proclamations were incorporated by the researcher.

\subsection{Sample Size and Selection}

In this study the researcher used non-probability sampling technique by using snowball sampling. Snowball sampling was applied to identify the displaced small-scale farm holders where the respondents recruit another respondent. Thereafter, 20 respondents were selected; out of them, minimally 7 (seven) unit of female headed households were chosen. Furthermore, government officials who are working on different level of government offices that have connection to the subject were selected purposively. Based on that 3(three) government officials were chosen such as 1 legal officer, 1 compensation officer, and 1 planning expert related to land use.

\subsection{Data Analysis Technique}

Qualitative method of data analysis was used by collecting information through observation, and semi-structured interview from small-scale farm holders and governmental officials. Following that, legislations, proclamation and constitutions coded by the researcher using Atlas ti-software. Thereafter, data generated from the primary source was interpreted, summarized and scrutinized by following the sequence of sub questions of the study.

\subsection{Validity and Reliability}

A case study strategy has high internal validity whereas its external validity is very less. Because, the smaller sample unit affect generalizability of the finding to the entire population. A verified way of improving the reliability and validity of the research is triangulation (Creswell, 2003). Triangulate means that use of various data sources of information. The study employed triangulation of information by using operationalization of concepts, primary and secondary data sources including data collection methods.

As mentioned by Golafashani (2003) to improve the reliability and validity of the study multi-method approaches has been used by the researcher towards generalizability of the study. Therefore, in this study various data collection methods were employed as such field observation, semi-structured interview and secondary document analysis used to collect the same data. Moreover, clear, rigorous, transparent interview questions were used, and the interview guide questions were also tested. Also, to confirm the reliability of the study various experts and fellow researchers reviewed the finding of the study.

Furthermore, to support observation and to make the study more reliable and valid, photograph of the IP is added. Content analysis also used from related proclamations, constitutions and legislations that helps to confirm the data that are collected using primary data collection methods.

\section{RESULTS AND DISCUSSION}

To what extent IPID affect small-scale farm holders natural, economic and social asset of small-scale farm holders explained through expropriation of landholdings using the power of eminent domain, property rights held by displaced farmers whose land were expropriated, and compensation for displaced farm holders that affected by expropriation, changes in livelihood asset (natural, economic and social) of the respondents in comparison to before displacement, and adaptation strategies used by households to deal with new changing conditions.

\section{Expropriation of Landholdings using the Power of Eminent Domain}

Government officials mentioned that 352 small scale farm holders displaced due to IPD. The study indicated that displaced farm holders loss their irrigable farm land (used to plant variety of variety of crops and vegetables), irrigable grazing land and trees.

Industrial park proclamation No. $886 / 2015$ for all industrial park development in the country stated that, “ Industrial park enterprise" means "a public, private or public-private enterprise owned by Ethiopians, foreigners or jointly and possess developed land under the industrial park through sub-lease or by renting or building a factory within the industrial park to engage in manufacturing activity or in service provision for profit making in accordance with Investment Proclamation No. 769/2012 and Investment Regulation, industrial park enterprise permit and industrial park enterprise agreement".

This proclamation put emphasis on the main objective of IPD namely to engage in provision of services and manufacturing activity for the purpose of profit maximization either established by foreign, and domestic investors or jointly.

Expropriation of Landholdings for public purpose proclamation No. 455/2005, Article 2 (5) of the law defined "public purpose" "as the use of land defined as such by the decision of the appropriate body inconformity with urban structure plan or development plan in order to ensure the interest of the peoples to acquire direct or indirect benefits from the use of theland and to consolidate sustainable socio-economic development". This proclamation put description about public purpose and its aim to expropriate private property in order to attain public benefit either direct or indirect advantages. As a result, the study showed that government used expropriation of landholdings for public purpose proclamation to construct IP in the study area. 
Article 3(1) of expropriation of landholdings proclamation stated that appropriate governmentauthority has the power to expropriate private property for public benefit: “A woreda or an urban administration shall, upon payment in advance of compensation in accordance with this Proclamation, have the power to expropriate rural or urban landholdings for public purpose where it believes that it should be used for a better development project to be carried out by public entities, private investors, cooperative societies or other organs, or where' such expropriation has been decided by the appropriate higher regional or federal government organ for the same purpose". This implies that lower level of government bodies has a power that decentralized from federal government to expropriate landholdings based on stated legislation. The study revealed that using the power that stated in the proclamation, officials in the study area expropriated land from small-scale landholders. Because, it isultimate power that government exercise the authority to take land from landholders.

After delegation of power given to lower government bodies, the proclamation declared notification of small-scale farm holders in advance: "Where a woreda or an urban administration decides to expropriate a landholding in accordance with Article 3 of this Proclamation, it shall notify the landholder in writing, indicating the time when the land has to be vacated and the amount of compensation to be paid".

This proclamtion specifies that small-scale farm holders have the right to be notified before expropriation happens.However, when officials decided to expropriate landholdings by any means organizing consultation with displaced farm holders about investment need, to get their consent or willingness of displaces related to the development need in the area is missed. Because, displaced farm holders have to agree to give their land for investment that carried out in their land in order to reduce forceful displacement. According to Adeola (2017) for development actors starting from free, prior, informed consent (FPIC) is significant to ensure that displaced peoples have feeling of belongingness for the procedure of consultation and to promote sustainability of development.

56 years old female headed household explained the situation as follow: "There was not any consultation organized; it was a meeting. In the meeting, the officials come and told us about what they want to do. It was not about a discussion and to know what I'm thinking about the land being taken and the amount of compensation payment. As a participant it was not about to take in to account my demand and my intention related to development that undertaken in my farm land".

The officials from Rural Land Management and Utilization Office team leader explains that: “We organized and prepared consultation through kebele in the presence of compensation officer and city administrator about amount of land needed for development, the need of measuring land size of farm holders, the amount of compensation that have to be paid per square meter for irrigable farm land, and grazing land. Thereafter, the experts started measuring the plot size in the presence of small-scale farm holders". A Goverenmt official feels they organized consultation with displaced farm holders. Inspite of this, the process seems notifying land holders about development need in the area. For the reason that, consultation involves taking in to consideration the need and demand of the participants rather than only informing what is already decided by higher officials.

Another elder respondent mentioned the process of land taking as follow:

"The officials tell us our land is needed by government for development activity. They specify the type of project that will be constructed in our farm land and the advantage of this development for our children's and for all displaced farm holders. The officials were not coming to discuss with us or to take in to consideration our demand. They only come to tells us our obligation to give our land for development. I didn't give my consent, but, if I like it or not, government could take my land, I can't change any decision and every process was obligatory than a discussion".

This indicated that displaced farm holders experienced forceful displacement from their livelihood without their consent and willingness to give their land for development.The finding of the study revealed that small-scale farm holders didn't have a right to appeal about the procedure of expropriation that carried out by the officials. For the reason that, the expropriation of landholdings for public purpose proclamation No.455/2005 of the country didn't specify the right to grievance related to expropriation.

Property Rights of Small-Scale Farm Holders

In FDRE constitution 1995, Article 40 (3) also specifies the right to ownership of land: "The right to ownership of rural and urban land, as well as of all-natural resources, is exclusively vested in the state and in the peoples of Ethiopia. Land is a common property of the Nations, Nationalities and Peoples of Ethiopia and shall not be subject to sale or to other means of exchange". This constitution stated that government is the possessor of urban and rural land including natural resource, and land is a joint property of citizens.

FDRE constitution Article 40 (4) also stated the pastoralist right to the land as follow: "Ethiopian peasants have right to obtain land without payment and the protection against eviction from their possession". FDRE constitution Article 40 (5) specified the landholders or the farmer's right stated as: "Ethiopian pastoralists have the right to free land for grazing and cultivation as well as the right not to be displaced from their own lands. The implementation shall be specified by law". This part of the constitution elaborates farmers have freeholding 
right to use it for cultivation or grazing land, and liberty to not displaced or evicted from their land unless government needs their property to use it for public interest.

One elderly female headed household specified her right to land as stated below:

"Yes, I have landholding right certificate and I pay tax for the government. I had the right to use or to produce variety of crops and vegetables on my land, including use as a grazing land. I had a right to give contract to another person to farm my land in order to produce products and to share the benefit together. Because, culturally in my area women can't farm the land but she can contract out the farm land for another person (man) to farm for her. I couldn't sell the land however; I used it for farming activity. After the death of my father, I was able to inherent his property and I could able to transfer for my children's. I was feeling like this is my own property, but now I don't have anything left".

Federal Democratic Republic of Ethiopia Rural Land Administration and Use proclamation, article 8 (5) stated that "any landholder shall have the right to transfer his rural land use right through inheritance to members of his/her family". This indicates that property transferred by succession. The landholders had the right to donate their land for his/her family members or otherlawful hires. The family members that had freeholding right to use their land might get it from her/hisfamily via bequest or gift. If really land is a joint property, it means landholders right is a brief of possession as well as the right to gain economic advantage of their land.The displaced landholders in the study area mentioned that they used their right to transfer their property to their family member, the right to use their land to produce vegetables, and cereal crops including right to manage their land. However, small-scale farm holders didn't have a right to sell the land rather than using it for agricultural activity, for planting trees, for grazing land and to construct residential house. Because, rural and urban land belongs to government.

The study indicated that IPD and government expropriation deprived property rights of small farm holders in the study area. For the reason that, before IPD, they had the right to use, right to manage related to how the land should be used, making the decision the type of crops to be planted and selling those products to get financial benefit. Also they had the right to withdrawal; it means to take something from the land such as to collect water, firewood and other products. The right to exclude means the right to prevent others from using it and the right to transfer through means of inheritance or donation for family members, and right to transfer to others via rental for specific period. Moreover, farm holders could able to rent out or lease their land to another farmer or investors from their landholding size.

The study revealed that due to various opportunities in the study area government locate industrial park in order to get FDI. Furthermore, IPD changes structural pattern of the area from agricultural land towards non-agricultural practice this deprived property rights of displaced farm holders.

Compensation for Displaced Farm Holders

In FDRE constitution, article 51(5) specifies the empowerment of federal government laws regarding the use of land is considered important to control the basis of conditions related to advance compensation payment "for private property expropriated for public purpose as specified under article 40 (8) of the constitution" as stated:

“Without prejudice to the right to private property, the government may expropriate private property for public purposes subject to payment in advance of compensation commensurate to the value of the property". This indicates that even government have power of eminent domain to expropriate private property for public benefit, but the proclamation obliged implementing agency to pay advance payment or commensurate compensation for displaced peoples. 'Commensurate' implies to fair compensation payment.

Based on Federal Democratic Republic of Ethiopia Rural Land Administration and Land Use Proclamation No. 456/2005, Article 7(3) stated that "holder of rural land who is evicted for the purpose of public use shall be given compensation proportional to the development he has made on the land and the property acquired or shall be given substitute land there on. Where the rural land holder is evicted by federal government the rate of compensation would be determined based on the federal land administration law". The finding of the study showed that IPD implemented as federal governmnt project in the study area. Though, responsibility of compensation provision including deciding the amount of compensation also determined in accordance with federal land administration legislation.

The payment of irrigable farm land was 57.30 ETB per care, the payment for irrigable grazing land was 29.50 ETB and whereas compensation for trees depends on the level of growth.

In August 2019, 1 USD $=29.525 E T B$, and 1 ETB $=0.0339$ USD

Based on the above, payment for irrigable farm land was 1.94 USD per square meter, for grazing land it was 0.991 USD per square meter.

Expropriation of landholdings for public purpose and payment of compensation proclamation No.455/2005, Article 8 (1) states that " $A$ rural land holder whose landholding has been permanently expropriate shall, in addition to the compensation payable under article 7 of the same proclamation, be paid displacement compensation which shall be equivalent to ten times the average annual income he secured during the five years preceding the expropriation of the land". This depicted out that compensation takes multitude forms of 
payment; it involves a percentage of crops that produced for past five year's productivity (1.94 USD) including next 10 years displacement compensation for displaced farm holders.

Noverthless, the study revealed that evaluators calculated the compensation by taking average productivity for the past 5 years and multiplying with the land size of farm holders. However, 10 years displacement compensation that specified in the legislation was not paid for displaced farm holders. For instance, if onefarm holder loses 1000 square meters of land, 1.94USD was the amount of irrigable land per square meterand 10 years displacement compensation. Compensation would be calculated, 1000 meters square $\mathrm{x} 1.94 \times 10$ years. The final compensation would be 19400USD. However, the officials calculated by only multiplying the amount of land per square meters with the five years preceding that was 1.94 equals to 1940USD.

One female headed household expressed her feeling about the compensation that provided as stated below:

"Yes, I received compensation 2677.2USD for irrigable farm land land. The experts were come in to the area to measure the size of my plot. Based on their measurement the total land that I have is 1380-meter square of land. However, I didn't really understand how they calculate my compensation. I feel like myland is gone for free and the officials cheating me".

The study revealed that the way of compensation calculation was not transparent for most of displaced farm holders. The officials took the same average of productivity for all farm holders. This shows that the way of taking average productivity of farm land was not realistic and factual. Because, farm holder's productivity varies in terms of their effort to be productive as well as fertility of their farm land.

The government officials from Rural Land Management and Utilization Office team leader elaborates the process of compensation payment as specified: "We told the displaced farm holders how we calculated the amount of compensation after the experts measure the size of their land, but it was paining them. They had grievances about the calculation of compensation by saying "this is not the right form of calculation". They were sent their grievance to the court about the amount of compensation. But, at that time it was difficult situation to have grievance, and some of displaced farm holders were spent a lot of month's even years to get solution for their grievance".

Displaced farm holders mentioned that there is no promptness payment of compensation and they recived their compensation after a year of expropriation. According to the officials from Rural land use administration and utilization team leader explained that: "the displaced farm holders were supposed to be paid at appropriate period of time because of the time it takes to measure the land size of the landholders and the time it takes to calculate the amount of compensation it extends the payment of compensation beyond 1 year".

According to official's response expropriation takes place starting from January- May 2015. Though, delayed compensation exposed the displaced farm holders to incur financial loss.

Council of ministers' regulation No.135/2007, article 15 specifies the provision of replacement rural land and the payment of displacement compensation: "Where land used for growing crops or a protected grass or pastoral land is expropriated for public purpose, the possessor of such land shall, as much as possible be provided with a plot of land capable of serving similar purpose". The government officials also explained their main reason why they didn't provide substitute land was because of the scarcity of rural land. So, they resort to pay compensation in cash for displaced farm holders.

Expropriation of landholdings for public purpose and payment of compensation proclamationNo.455/2005, article 13 (1) stated the responsibility of woreda or local authorities whose implemented expropriation shall rehabilitate displaced peoples to the extent possible additional to the payment of compensation. The study showed that local authorities didn't rehabilitate displaced small-scale farm holders after expropriation takes place rather only providing monetary compensation.

One male headed household specified about the inadequate payment of compensation in this way:

"I received 2350.21 USD for 1193 square meters of irrigable farm land. The payment is insignificant, and it is meager amount, and it would be my two years productivity on my farm land. I couldn't even cover the food expense of my household for two years. When the officials calculate compensation, they didn't take in to consideration the economic activity that undertaken in my farm land including my productivity. If they consider that the payment will be better than the amount that I received".

The study showed that the amount of compensation is insufficient to meet the demand and the need of displaced farm holders even if to restore their lost asset and their livelihood. The officials also described that government's financial scarcity to provide more money for displaced farmholders.

Nevertheless, some displaced farm holders explained that they received 1.79USD for irrigable farm land that is 0.17 USD lower than the stated amount of compensation and the officials took the money by putting a reason that need of paying for individuals who work in finance department. Due to high level of corruption the amount of compensation provided for displaced farm holders whose land is expropriated is very small. The state delivers the money, but it goes to wrong pocket the local officials and assessors take good amount of it. 


\section{Change in Livelihood of Small-Scale Farm Holders}

Change in Natural Asset

As indicated displaced farm holders in the study area were agrarian society their life depends on farming activities as a key means of livelihood. There means of living were depend on availability and accessibility of farm land to produce variety of crops \& vegetables. The study revealed that displaced farm holders only received monetary compensation for the past year productivity rather than getting replacement value, current or market value, and future value of land. In addition, displaced farm holders weren't compensated in kind like getting replacement land that intensifies there vulnerability.

Council of ministers regulation No.135/2007, payment of compensation for the property situated on landholding expropriated for public purpose, article 15 explains provision of replacement land: "Where land used for growing crops or a protected grass or pastoral land is expropriated for public purpose, the possessor of such land shall, as much as possible be provided with a plot of land capable of serving similar purpose".

Government officials mentioned that according to legislation rural land holders whose land were expropriated for public purpose shall be compensated replacement land that serves similar purpose due to scarcity of rural land monetary payment of compensation for their loss was implemented. That is the reason that, after displacement they didn't have access to farm land, grazing land and tress. The respondents also stated that monetary compensation paid by governmnt was not enough to buy new land because the payment was meager amount. The price to buy legal land in the city is very expensive whereas rural land can't be sold. Because, farm holders have unlimited use right and land belongs to government. Therefore, this hampers their ability to restore their lost asset (means of survival).

Change in Economic asset of small-scale farm holders So many years before government was built irrigation canal for farm holders in the study area. Before displacement, the displaced farm holders were economically sound; they were able to produce various vegetables and cereal crops at least 2 times in year using irrigation. Due to that they were finaicially capable to send their childrens to school, to access health facilities for their family including provision of good food for their household members. In time when the IP construction started after expropriation government bodies closed the irrigation canal. Moreover, irrigation was enables small scale farm holders to use more varied cropping patterns to suitably farm from lower-value staple production to higher-value market-oriented productivity.

A male headed household explained how it was looked like their economic condition related to their productivity before and after displacement happens as follow as:

"Before displacement I was a farmer, I lost more than $3000 \mathrm{~m}^{2}$ of irrigable land. I used it to produce vegetables such as onion, cabbage and cereal crops like maize, teff at least 2 times in a year. The farm land used to help me harvest 12 -13 quintal and above, because the land was too fertile. Out of $3000 \mathrm{~m}^{2}$ of irrigable land 530 square meter of the land was irrigable grazing land and the remaining $2,470 m^{2}$ was irrigable farm land. At this time, I'm working as a security guard, I spent a year and in this work I get 44.47USD per month. I have 6 family members, and I'm the only one doing job. The salary that I get is not enough even to cover the daily consumption of my family members, but I don't have any choice".

The study showed that previously every family member had contributed for family income by doing agricultural activities and selling agricultural products to the market. But, following displacement the family's income has gone down or reduced considerably, because peoples have lost their source of income as well as their source of employment. As a result, the number of earning members in the family has also diminished. Even though the household members who earn income by doing some job either temporary or permanently, the salary or wage they used to get is very meager amount.

The establishment of IP in the study area by federal government is to get FDI by attracting foreign investors and investors are highly interested to invest in the country. Because, one of government instrument used to attract investors is the availability of cheap labor force. For that, the aim of the investors is to maximize their profit rather than paying fair amount of wage as well as salary for the workers.

71 years old male headed household explain the effect of displacement in his economic condition as specified:

"Yes, I lost $870 \mathrm{~m}^{2}$ irrigable farm land, it was productive that I was producing teff, lettuce, onion, tomato at least 2 times in a year and 109 square meter of irrigable grazing land, I feed this for my domestic animals, and I used to sell the remaining grass for other peoples who need to buy for their domestic animals. Totally, 979 meters square of land. Before displacement, I was farming and rearing cattle at the same time. I didn't know how much I was getting in a month because, the productivity of crops was at least two times in a year, and vegetables 3 times in a year depends on type of vegetable that I want to produceincluding rearing domestic animals like sheep, got, donkey and others. Currently, after displacement I didn't do any job because I'm older to work as a daily laborer and they didn't hire me as a security guard too. In addition, I'm not educated, and it is difficult to get any other alternative job. And also, I sold all domestic animals because I don't have anything to feed them and I used the money to cover the cost of household expenses". 
The finding of the study indicted that joblessness is the key effect of IPID in the study area.The respondents were also unanimously raised about unemployed for themselves and even their children in the IP. Nevertheless, in time of notifying farm holders about development need in the area officials promised to provide job opportunities for displaced farm holders. The promise is not realized after IP constructed in their farm land except few numbers of displaced farm holders and farm holders' children work in the IP as a daily laborer, security guard and cleaner.The observation made during fieldwork found out that most displaced small-scale farm holders especially youngers, women's and elder peoples stayed idle at home and they are more vulnerable than the remains.

Change in Social Asset Property rights to land are also associated among households. It is very essential to think beyond ownership or ultimate purpose of land and benefits that derive from land. The respondents explained that the community live in the same area before and after expropriation take place. Because, there residential home is on hill area and also far away from their farm land, grazing land and trees coverage. However, some household heads and youths migrate to another area to find a better life and to support the remaining family in the community. If there will be resettlement to another area their social cost might be high and worse. But it doesn't mean that displacement from there means of survival have little effect on their social values. There are changes that happened after they lose their farm land such as change in social relation, disappearance of social association and difficulty to participate in different social supporting mechanisms.

In kurangoye community there was a social gathering like coffee ceremony that performed among neighbors. This ceremony takes place within specified time either in lunch time or between lunch and dinner time. Before expropriation, throughout the ceremony they talk day to-day occasions that happens, confronts or problems faced in managing their family, sharing information about agricultural activity and their productivity including market conditions for their product. They seek advice to each other on various parts of their means of living and share one another's experience.

64 years old female headed household specified what her social relation looks like with her neighbors before and after displacement as follow: "Before my land was taken, we used to eat together with my neighbors, we have coffee ceremony together, we consult each other, and we visit sick person together by having something for the patient. At this time after losing farm land, everyone struggles to feed their own family".

The study showed that social relation in the community is affected due to financial incapability of small-scale farm holders after they lose their land; it becomes very challenging to get food for themselves let alone for their neighbors.

One of displaced male headed household mentioned social association that they had before and after expropriation was undertaken in the area as stated:

"I had participated in informal association among my neighbors like labor association working together in the farm area. It increased our relationship and collaboration among my neighbors and peoples in the community. When I need to plant crops, in time of weeding and harvest my products, I call my neighbors to help me and they come over to support me. At the same time, when they need support, I will go to in their farm land to support them, if I have another thing to do, and I send my son to in place of me. When the land was taken, these associations also had gone. Because, most of us in this district totally lost our farm land, we didn't have any remaining land except some farmers have small parcel that remains from expropriation".

The finding of study revealed that during spring and autumn the farm holders get together when they were sowing, weeding crops and harvesting the agricultural products. For that, in Ethiopia farming activity performed in traditional way like ploughing by oxen. Modern agricultural technologies are very rare or almost none. Farming relies on labor force of farmers and farm holders support each other in order to facilitate their farming activity. DIP vanished the farm holders' labor association as it depends on the availability of agricultural farm land.

A female headed household explained mutual group of supporting mechanisms that was established in the community and existed for a long it comes from generation to generation as depicted as:

"Idir or kere are very indispensable mechanisms that are essential as insurance for my families and relatives. I do not know who will die, when, how, and I have to be in the support group, and if I did not attend in the funerals and wedding's ceremony after the peoples tells me or after they invited me by taking money or grains to their place to share their happiness or sorrow. Those peoples also didn't attend any of these ceremonies that I would organize. Because, it is giving and taking, you will do something for them, and you will get something as return. After land was taken, attending in those ceremony become very challenging because of my financial incapability. However, for condolence giving something is mandatory even if I will give from what I want to eat or from household consumption".

The study indicated that there is a mutual supporting mechanism of displaced farm holders in their community. For that, a good measurement of cohesion of community is the capability of members to support each other. However, this mutual supporting mechanism somehow in trouble because of reduction of their economy. These shows that displaced farm holders become incapabile to cover expenditures for social life situations such as sickness, death or funerals, and wedding ceremonies in the community. Nevertheless, culturally for those needs everyone gives high priority than personal needs. Those social supporting mechanisms in the study area called 
"Idir" locally called "Kere". This mutual supporting group is very helpful to handel major contribution or to share expenses in time of death in families. As farm holders are engaged more in their economic pursuit, they will hardly organize and collect funds for such supporting mechanisms. Moreover, families face economic marginalization due to losing their economic power. This economic marginalization supplemented by social and psychological marginalization and these related to fall of their social status and loss of their confidence intensify their vulnerability.

On the other way round school drop out of displaced farm holders' children's also increases. This is because of their financial difficulties to cover their children's educational facilities and at the same time to reduce their expenditure. The observation in the field also indicated a gathering of youngsters' sittting the whole day in corner of street and they become social vices like chewing "Catha edulis" or "khat", smoking tobacco and stealing. The study also revealed that economical marginalization made some displaced farm holders incapable to take care of their sick family to health center. Furthermore, this situation has adverseeffect on children's and women's health as they are not capable to meet nutritional need of their body.

\section{Adaptation Strategies of Displaced Farm Holders}

The displaced farm holders had been farming for generations, received little and small amount of compensation for IPD which carried out as a public project. The displaced small-scale farm holder's capacity to exercise their choice and voice continued feeble. The study showed that a means of livelihood for displaced small-scale farm holders after displacement depends on non-farming employment; children drop out of school in order to work and fail to adapt the situation of learing and working. Non- farming employment involve either temporarily working as a daily laborer (daily employment) and permanent employment like a security guard and a cleaner.

The study indicated that out of 20 respondents two-male headed households work as a security guard in the IP. Another two displaced farm holder work as a daily laborer in the IP like digging holes, 1 youngest farm holder's child work as a cleaner in the IP. However, the remaining displaced small-scale farm holders failed to adapt and they didn't have any job.

Government officials stated that security guards for IP were selected based on their political affiliation. Government for its purpose trained some farmers selectively in rural area as local security force and they have guns locally called "Militia". Only those selected displaced farm holders get job as a security guard in the IP and other displaced cannot be a security guard in the investment that has undertaken in their farm land.

\section{CONCLUSIONS AND POLICY IMPLICATIONS}

Farming was the main means of livelihood for displaced farm holders. It was settled that every development projects are meant for enormous advantage for the society. However, appears to be a subset of displacement whereas the cost incurred also borne by displaced farm holders.

- The study showed that there is no consultation organized by government officials. Thereafter, the officlas compulsory acquired the land without the farm holders' consent. However, preparing consulation between displaced peoples and goverenmt, including getting thewillingness of displaced farm holders is very essential to take the participants future need and to achieve sustainability development goals of the country.

- The Study showed that government expropriated landholdings to construct IP using "expropriation of landholdings for public purpose proclamation of the country No.455/2005". In this proclamation the term public purpose has wide interpretation; it is very vague and broad. Its denotation allows taking property from one individual and providing it to any other individual without the requirement to ascertain the interest of the public at all. Moreover, no proper guidelines are provided to interpret it in well manner. Additionaly, the proclamation didn't support the arrangement of consultation including sending grievance to administrative organs related to compulsory land acquisition.

- $\quad$ The study showed IPD deprived property rights of displaced small-scale farm holders'. For that, IPD changed the structural pattern of the area towards non-farming area. Before expropration, displaced farm holders were enjoying the liberty to use their land for unlimited time period, right to manage related to how the land should be used, making decision about type of crops to be planted. They also had the right to withdrawal resources from their land, right to exclude others from using their land, and the right to transfer through means of inheritance or bequest for family members, and the right to transfer to others via rental.

- $\quad$ The finding of the study showed that displaced farm holders received 1.94 USD for irrigable farm land that is the past five years productivity, 0.991 USD for grazing land and payment for trees depends on level of growth. In legislation it specified that compensation provision for 5 years proceeding including 10 years displacement compensation. Nonetheless, there is no any justification that outlined to support why 5 years preceding and 10 years displacement compensation. This doesn't consider price inflation and increment of market price for goods and services.

- Improper calculation of compensation, delayed payment of compensation, small amount of monetary compensation due to lack of budget from government, and corruption created under compensation. Just and fair 
compensation is critically necessary to make the living condition and financial situation of the displaced farm holders to remain the same or better than post expropriation period.

- $\quad$ The study depicted that displaced farm holders weren't compensated in kind as well as they were not even get rehabilitation. However, the proclamation stated about provision of substitution land as well as the need of rehabilitation of the displaced land holders is quite critical.

- $\quad$ The finding of the study indicated that government expropriated farm land, grazing land and forest from small land holders. Moreover, they didn't have access to natural resource, farm land and grazing land. This creates landlessness of displaced peoples either partly or totally loss of farm land, grazing land and any other natural resources. As a result, there is an interconnection between vulnerability context and natural asset.

- Loss of income and loss of agricultural activity has a major impact on the economy of displaced farm holders. The finding of the study revealed that after displacement the occupational pattern of most displaced farm holders' changes to unemployment or joblessness.

- As the finding of the study explained that due to landlessness and difficulty of getting any other alternative job or income generating activity the displaced farm holders' social relation, labour association and mutual supporting mechanisms (Idir or kere) are becoming reduced and feeble.

- $\quad$ The capability of displaced farm holders to restore their livelihood after land has been taken based on obtaining job in non-agricultural sectors. Nonetheless, this doesn't indicate they are better off after displacement. The study indentified that most of displaced farm holders are fails to adapt to the new changing condition.

As a result, the legislation should determine what activities constitutes a public purpose and the meaning of the term should be sufficiently clear about direct as well as indirect achievement of public interest. In view of that, expropriation happens only to attain some particular and clear public purpose. Because, the definition should have to specify nature of benefit that displaced peoples is awaited to drive from the planned project which land acquisition is carried out.

The displaced farm holders should be given room to appeal to court or to any other administrative organs to stop administrative misuse of state power and should have the right to challenge decisions related to expropriation procedure. Where government acquired private property and transferred it to investors those who are private with the aim that changes in possession or utilization might generate advantage for the public. At least government should consider profit potential of investmentthat carried out in the expropriated land in time of compensation payment for displaced peoples.

Government should create sustainable measure for displaced small-scale farm holders to reduce risks and impovershiment. Thereafter, IPD on property of displaced farm holders should have to share benefit that driven from the investment for displaces to reduce their impoverishment and to attain the aim of sustainable development goals by lifting up poor displaces from absolute poverty line. Responsible bodies should have to provide an alternative asset for displaced farm holders such as substitute land, access to credit; technical training will help the displaced people to restore their lost asset.

Furthermore, there is a need of establishing a grand rehabilitation project that continually resolve displaced farm holders post trauma and impoverishment risks.

\section{References}

Adeola, R., 2017. The Legal Protection of Development-Induced Displaced Persons in African. African Journal of Legal Studies, 10 (1), pp. 91-104.

Alemu, G. T., 2015. Land Expropriation and Compensation Payment in Ethiopia.

Ambaye, D. W., 2009. Land valuation for expropriation in Ethiopia: valuation methods and adequacy of compensation. Paper presented a 7th FIG Regional Conference: Spatial data serving people: land governance and the environment - building the capacity, Hanoi, Vietnam, 19-22 October 2009. Copenhagen: International Federation of Surveyors. Available at: https://www.fig.net/resources/proceedings/fig_proceedings/vietnam/papers/ts04c/ts04c_ambaye_3753.pdf .

Azmach, E. W., 2019. Regulating Industrial Parks Development in Ethiopia: A Critical Analysis. Beijing L.Rev., 10 pp. 23.

Azuela, A. and Herrera-Martin, C. 2009. Taking land around the world: international trends in the expropriation for urban and infrastructure projects.

Cernea, M. M., 2000. Risks, safeguards and reconstruction: A model for population displacement and resettlement. Economic and Political Weekly, pp. 3659-3678.

Cernea, M. M., 2008. Compensation and benefit sharing: Why resettlements policies and practices must be reformed. Water Science and Engineering, 1 (1), pp. 89-120. Available at: http://ac.elscdn.com/S1674237015300211/1-s2.0-S1674237015300211-main.pdf?_tid=cdfde184-d7f9-11e6-a32e00000aab0f6b\&acdnat $=1484138038 \_6 a 7795 a 7604 f e 7 d 7 a 2 c 3 d b e a c 254691 \mathrm{c}$.

Chambers, R. and Conway, G., 1992. Sustainable rural livelihoods: practical concepts for the 21st century. Institute of Development Studies (UK). 
Creswell, J. W. (2003). Research Design: Qualitative, Quantitative and Mixed Methods Approaches. (2nd Ed.). London, Sage Publications.

De Wet, C., 2009. Does development displace ethics? The challenge of forced resettlement. SAR Press, Santa Fe, NM. pp. 96.

DFID, 1999. Sustainable Livelihood Guidance Sheets. Available at: https://www.ennonline.net/attachments/872/section2.pdf.

DFID, 2000. Sustainable Livelihoods Approach and its Framework. Available at: http://www.glopp.ch/B7/en/multimedia/B7_1_pdf2.pdf.

Downing, T. E., 2002. Avoiding New Poverty: Mining-Induced Displacement and Resettlement, Mining, Minerals and Sustainable Development. International Institute for Environment and Development and World Business Council for Sustainable Development, London.

Eerd, M. v. and Banerjee, B., 2013. Evictions, acquisition, expropriation and compensation: practices and selected case studies. Working paper 1. Nairobi: United Nations Human Settlements Programme. Available at: http://www.gltn.net/jdownloads/GLTN\%20Documents/working_paper_on_evictions_etc_11feb2013_1.pdf.

Ellis, F., 2000. Rural livelihoods and diversity in developing countries. Oxford university press.

Feder, G. and Feeny, D. 1991. Land tenure and property rights: Theory and implications for development policy. The World Bank Economic Review, 5 (1), pp. 135-153.

Federal Negarit Gazeta of Federal Democratic Republic of Ethiopia. Federal Democratic Republic of Ethiopia constitution. 1995.

Federal Negarit Gazeta of the Federal Democratic Republic of Ethiopia: Proclamation No. 455/2005 Expropriation of Landholdings for Public Purposes and Payment of Compensation, 2005. ADDIS ABABA.

Federal Negarit Gazeta of Federal Democratic Republic of Ethiopia. Proclamation No. 456/2005 Federal Rural Land Administration, 2005.

Federal Negarit Gazeta of Federal Democratic Republic of Ethiopia: Council of Minsters Regulation No.135/2007, payment of compensation for property situated on landholding expropriated for public purposes council of ministers' regulation. 2007. Addis Ababa.

Federal Negarit Gazette of the Federal Democratic Republic of Ethiopia: Industrial Parks proclamation No. 886/2015, 2015. ADDIS ABABA.

Golafshani, N. (2003). Understanding Reliability and Validity in Qualitative Research. The Qualitative Report, 8 (4), 597-607.

Hussein, K., 2002. Livelihoods approaches compared. London, Department for International Development.

IFC, 2012. Standard Performance 5: Land Acquisition and Involuntary Resettlement. International Finance Corporation, pp. 10.

Jacobs, H. M., 2013. Private property and human rights: A mismatch in the 21st century? International Journal of Social Welfare, 22 pp. S85-S101.

Jamart, A., 2010. The Power of Eminent Domain. Compulsory purchase in Adminstrative and Comparative public law. Available at: http://www.sciencespo.fr/chaire-madp/sites/sciencespo.fr.chaire madp/files/power_of_eminent_domain.pdf.

Krantz, L., 2001. The sustainable livelihood approach to poverty reduction. SIDA.Division for Policy and SocioEconomic Analysis, 44.

Lone, A. R., 2014. Development Induced Displacement. (2321-1098), pp. 216-224. Available at: https://www.academia.edu/8723303/Raoofs_Paper_Development_Induced_Displacement.

McDonald-Wilmsen, B. and Webber, M. 2010. Dams and Displacement: Raising the Standards and Broadening the Research Agenda. Water Alternatives.

Mendes, A. P. F., Bertella, M. A. and Teixeira, R. F. 2014. Industrialization in Sub-Saharan Africa and import substitution policy. Brazilian Journal of Political Economy, 34 (1), pp. 120-138.

Merriam, H. D., 2007. Eminent Domain. Available at: http://www.rc.com/documents/Merriam.pdf

Naika, B., 2016. Land Acquisition and Development Induced Displacement: India and international legal framework. Available at: http://www.ili.ac.in/pdf/p6_balaji.pdf.

Navarra, M., Niehof, A., Van Der Vaart, W., van der Horst, H., et al., 2012. The disruption and rebuilding of social capital in involuntary resettlement in the Philippines and Indonesia. International Journal of Social Sciences and Humanity Studies, 4 (2), pp. 307-324.

Noufal, P. and Ramachandran, K. 2016. Industrial parks and regional economic development: Select literature review.

Payne, G., 2001. Urban land policy options: Titles or rights? Habitat International, 25 pp. 415-429.

Randell, H., 2016. The short-term impacts of development-induced displacement on wealth and subjective wellbeing in the Brazilian Amazon. World Development, 87 pp. 385-400.

Reddy, G., Smyth, E. and Steyn, M., 2017. Land access and resettlement: a guide to best practice. Routledge. 
Robinson, W. C., 2003. Risks and rights: The causes, consequences, and challenges of development-induced displacement.

Sayatham, M. and Suhardiman, D. 2015. Hydropower resettlement and livelihood adaptation: The Nam Mang 3 project in Laos. Water Resources and Rural Development, 5 pp. 17-30.

Scoones, I., 1998. Sustainable rural livelihoods: a framework for analysis.

Stanley, J., 2009. Development Induced Displacement and Resettlement. FMO Research Guide: Development Induced Displacement and Resettlement.

Terminski, B., 2013. Development-induced displacement and resettlement: Theoretical frameworks and current challenges. Development, 10 pp. 101.

Vanclay, F., 2017. Project-induced displacement and resettlement: from impoverishment risks to an opportunity for development? Impact Assessment and Project Appraisal, 35 (1), pp. 3-21.

Van Thiel, S., 2014. Research methods in public administration and public management: an introduction. Routledge.

Viitanen, K., 2002. Just compensation in expropriation?

Wilmsen.B.,Webber.M and Yuefang.D.2011.Development for whom? Rural to urban resettlement at the Three Gorges Dam, China. Asian Studies Reviewwu,35(1), pp.21-42.

Woltjer, J., 2014. A global review on peri-urban development and planning. Groningen: University of Groningen. 